\title{
Induction of Myocardial Nitric Oxide Synthase by Cardiac Allograft Rejection
}

\author{
Xiaochun Yang, Nepal Chowdhury, Bolin Cai, Jerold Brett, Charles Marboe, Robert R. Sciacca, Robert E. Michler, \\ and Paul J. Cannon \\ Departments of Medicine and Surgery, College of Physicians and Surgeons, Columbia University, New York 10032
}

\begin{abstract}
Cardiac transplantation, effective therapy for end-stage heart failure, is frequently complicated by allograft rejection, the mechanisms of which remain incompletely understood. Nitric oxide (NO), a vasodilator which is cytotoxic and negatively inotropic, can be produced in large amounts by an inducible NO synthase (iNOS) in response to cytokines. To investigate whether iNOS is induced during cardiac allograft rejection, hearts from Lewis or Wistar-Furth rats were transplanted into Lewis recipients. At day 5, allogeneic grafts manifested reduced contractility and histologic evidence of rejection (inflammatory infiltrate, edema, necrosis of myocytes). The mRNA for iNOS and iNOS protein were detected in ventricular homogenates and in isolated cardiac myocytes from rejecting allogeneic grafts but not in tissue and myocytes from syngeneic control grafts. Immunocytochemistry showed increased iNOS staining in infiltrating macrophages and in microvascular endothelial cells and cardiac muscle fibers and also in isolated purified cardiac myocytes from the rejecting allografts. Using a myocardial cytosolic iNOS preparation, nitrite formation from $L$-arginine and $\left[{ }^{3} \mathrm{H}\right]$ citrulline formation from $\left[{ }^{3} \mathrm{H}\right] \mathrm{L}$-arginine were increased significantly in the rejecting allogeneic grafts $(P$ $<0.01$ ). Myocardial cyclic GMP was also increased significantly $(P<0.05)$. The data indicate myocardial iNOS mRNA, protein and enzyme activity are induced in infiltrating macrophages and cardiac myocytes of the rejecting allogeneic grafts. Synthesis of NO by iNOS may contribute to myocyte necrosis and ventricular failure during cardiac allograft rejection. (J. Clin. Invest. 1994. 94:714-721.) Key words: heart transplantation • inducible NO synthase • allograft rejection
\end{abstract}

\section{Introduction}

Cardiac transplantation is recognized as the most effective therapy for end-stage heart failure with one and five year survival rates currently exceeding 80 and $65 \%$, respectively (1). Despite this success, allograft rejection continues to be a major obstacle to long-term survival. This results in diminished ventricular contractile performance and necrosis of cardiac myocytes which are manifested clinically by congestive failure, low cardiac out-

Address correspondence to Paul J. Cannon, M.D., Columbia University, 630 West 168th Street, New York, NY 10032.

Received for publication 16 September 1993 and in revised form 7 February 1994.

J. Clin. Invest.

(c) The American Society for Clinical Investigation, Inc.

$0021-9738 / 94 / 08 / 0714 / 08 \quad \$ 2.00$

Volume 94, August 1994, 714-721 put, hypotension, and reduced pressor responses to catecholamines. Allograft rejection also results in the development of accelerated atherosclerosis in the coronary arteries of the transplanted heart which is manifested clinically by myocardial infarction and sudden death (2). There is a large body of knowledge concerning the immunological reactions which are involved in cardiac allograft rejection $(3,4)$. However, the cellular and biochemical mechanisms responsible for the development of contractile failure and necrosis of cardiac myocytes during cardiac allograft rejection are poorly understood.

The oxidation of L-arginine to biologically active nitric ox$\operatorname{ide}(\mathrm{NO})^{1}$ is important in a wide variety of physiological and pathological processes (5-7). A family of enzymes, the nitric oxide synthases (NOS), catalyze the oxidation of one of the terminal guanidino nitrogens of L-arginine to yield NO and citrulline. In effector cells NO interacts with soluble guanylyl cyclases to increase formation of cyclic GMP and to initiate biological responses. Constitutive nitric oxide synthases require calcium and calmodulin as cofactors. Constitutive NOS in endothelial cells generates low levels of NO in response to hormones or sheer stress which increases levels of cyclic GMP in platelets and in endothelial and vascular smooth muscle cells promoting vasodilation, inhibition of platelet adhesion, and aggregation and inhibition of leukocyte adhesion. Constitutive NOS in brain and neurons of the nonadrenergic, noncholinergic nervous system generates NO which functions as a neurotransmitter (57). Inducible nitric oxide synthases (iNOS) are not present under basal conditions, but are expressed in response to cytokines or bacterial endotoxin in macrophages, endothelial cells, vascular smooth muscle cells, and cardiac myocytes (5-7). Inducible NO synthases do not require calcium and calmodulin as cofactors and generate substantially larger amounts of NO for longer periods of time. NO produced by iNOS in activated macrophages is cytotoxic and involved in their antimicrobial actions. NO produced by iNOS in vascular smooth muscle cells and cardiac myocytes in response to bacterial endotoxin has been implicated in the pathogenesis of hypotension in association with infection by gram negative bacteria (5).

In cardiac tissue NO production may occur via both constitutive and inducible NO synthases. The basal production of NO by constitutive NOS in coronary arterial and microvascular endothelial cells is important in the maintenance of coronary vascular tone $(8,9)$. NO production by endocardial and endothelial cells may also influence myocardial contraction $(8,10$ 12 ). NO produced by constitutive NOS in cardiac myocytes does not appear from current evidence to have a major influence on basal contractility of cardiac myocytes but it can modulate heart rate responses to muscarinic cholinergic agonists and inhibit the inotropic response to $\beta$-adrenergic agonists $(11,12)$. Inducible NOS has been expressed in normal ventricular tissue

1. Abbreviations used in this paper: iNOS, inducible nitric oxide synthases; NO, nitric oxide; NOS nitric oxide synthases. 
and cardiac myocytes in response to cytokines (TNF $\alpha, \mathrm{IL}-1 \beta$, IFN- $\gamma)$ and bacterial endotoxin $(5,6,13-15)$. The continuous and large production of NO by iNOS in cardiac myocytes has been shown to influence heart rate and to modulate myocardial contractile responses $(14,16)$.

Current evidence indicates that during allograft rejection there is a major release of cytokines by activated $\mathrm{T}$ lymphocytes and macrophages which participate in the immune reaction to foreign HLA and other antigens present in endothelial and other cells of the transplanted organ $(3,4,17)$. Cytokines, particularly those released by the $T_{h-1}$ subset of lymphocytes, have been shown to promote the expression of iNOS in several systems $(18,19)$. Accordingly, the present study was undertaken to investigate the hypothesis that during cardiac allograft rejection, iNOS mRNA, protein, and enzyme activity are induced in cardiac myocytes and in activated macrophages which infiltrate the myocardium during the immunologically induced inflammatory reaction.

\section{Methods}

Cardiac transplantation. Male Lewis (TR-11) and Wistar-Furth (WF, RT-1u) rats weighing 180-300 g were purchased from Harlan Sprague Dawley, Inc. (Indianapolis, IN). The animals were maintained on a 12$\mathrm{h}$ light/dark cycle and fed a commercially available rat chow diet and tap water ad lib. Heterotopic abdominal heart transplantation was performed as previously described according to the method of Ono and Lindsay (20). Transplanted hearts in the abdomen were palpated daily; rejection was determined by weakening of the heart beat and confirmed by inspection at laparotomy and by histological examination. Syngeneic Lewis to Lewis abdominal heart transplants were performed by the same technique. Hearts were removed at days 1,3 , and 5 for pathological or biochemical examinations.

Preparation of myocytes. Isolated ventricular myocytes were prepared aseptically using a technique modified from Wittenberg and Robinson (21) and Osbakken et al. (22). Rats were heparinized (1,500 U/ $\mathrm{kg}$ ) and anesthetized with chloral hydrate; the transplanted hearts were excised and retrogradely perfused with a modified calcium-free HepesRinger solution containing $111 \mathrm{mM} \mathrm{NaCl}, 5.4 \mathrm{mM} \mathrm{KCl}, 4.2 \mathrm{mM}$ $\mathrm{NaHCO}_{3}, 1.5 \mathrm{mM} \mathrm{NaH} \mathrm{PO}_{4}, 1.6 \mathrm{mM} \mathrm{MgCl}, 20 \mathrm{mM}$ Hepes acids, 5.4 $\mathrm{mM}$ glucose, $4.1 \mathrm{mM}$ L-glutamine, $10 \mathrm{mM}$ Taurine (Sigma Chemical Co., St. Louis, MO), $1 \times$ minimum essential media vitamin solution (MEM, GIBCO BRL, Gaithersburg, MD) and $1 \times$ MEM amino acids solution (GIBCO BRL). The final osmolarity was $292 \mathrm{mOsm}$, pH 7.20. After perfusion with $20 \mathrm{ml}$ (nonrecirculating) of this solution gassed with $100 \% \mathrm{O}_{2}$, the hearts were perfused for another $30 \mathrm{~min}$ with this oxygenated solution containing $0.07 \%$ collagenase B (BoehringerMannheim Corp., Indianapolis, IN). Ventricular tissue was minced and incubated in a shaker bath at $33^{\circ} \mathrm{C}$ for $15-20 \mathrm{~min}$ in $10 \mathrm{ml}$ of perfusion solution supplemented with $14 \mathrm{mg}$ collagenase $\mathrm{B}, \mathbf{4 0} \mathrm{mg}$ fatty acid free bovine serum albumin (BSA; Sigma Chemical Co.) and $0.88 \mathrm{mg} \mathrm{cal-}$ cium. The released cells were collected. The process was repeated four or five times with fresh collagenase solution. The collected cells were filtered with nylon mesh and washed with Dulbecco's modified Eagle's medium (DME; GIBCO BRL). Myocytes were purified from nonmyocytic cells with a Percoll (Sigma Chemical Co.) density gradient system (23). Myocytes sedimenting between 1.082 and $1.061 \mathrm{~g} / \mathrm{ml}$ were resuspended in DME and plated in laminin-coated dishes (60 $\mu \mathrm{g}$ per $100-$ mm dish; Sigma Chemical Co.) at a density of $1 \times 10^{6}$ cells per dish. The medium was changed after $1 \mathrm{~h}$ of incubation to remove most damaged and contaminating cells. The cells that sedimented between 1.061 and $1.050 \mathrm{~g} / \mathrm{ml}$ were collected separately, and constituted a mononuclear cell fraction.

Immunocytochemistry. The transplanted hearts were removed and ventricular tissue was placed in cryoprotectant (Polyfreeze; Polysciences, Warrington, PA) and snap frozen in dry ice/methanol. Frozen sections, or isolated myocytes, were fixed in acetone for $5 \mathrm{~min}$, rinsed in phosphate buffered saline (PBS) and incubated in blocking buffer (PBS containing $1 \%$ bovine serum albumin and $2 \%$ normal goat serum) for $30 \mathrm{~min}$ at $37^{\circ} \mathrm{C}$. Slides were incubated with rabbit anti-macrophage iNOS antiserum $(7 \mu \mathrm{g} / \mathrm{ml})$ for $45 \mathrm{~min}$ at $37^{\circ} \mathrm{C}$, washed in PBS and exposed to peroxidase conjugated goat anti-rabbit immunoglobulin (Sigma Chemical Co.). Localization of peroxidase conjugates was revealed using amino ethylcarbazole (AEC) as the chromogen. The antiserum, a generous gift of Dr. David Harrison (Emory University, Atlanta, GA) was a rabbit polyclonal antiserum raised against peptide sequence 117-128 of mouse macrophage iNOS. Control sections were exposed to pooled nonimmune rabbit IgG at equivalent protein concentration and processed as above.

Northern analysis. Poly(A) RNA from ventricular homogenates and isolated myocytes was prepared by the method of Chomozynski and Sacchi (24), and isolated by Oligo (dT) cellulose absorption (Fast Track mRNA isolation kit; Invitrogen, San Diego, CA). Poly (A) RNA from ventricular homogenates and from isolated myocytes was electrophoresed on $1.0 \%$ agarose gels containing $15 \%$ formaldehyde in $20 \mathrm{mM}$ MOPS, $5 \mathrm{mM}$ sodium acetate, and $1 \mathrm{mM}$ EDTA and transferred to nitrocellulose membranes. The blots were prehibridized at $42^{\circ} \mathrm{C}$ for 6 $\mathrm{h}$ in $5 \times \mathrm{SSC}, 5 \times$ Denhart's solution containing $50 \%$ formamide, 0.125 $\mathrm{mg} / \mathrm{ml}$ salmon testes DNA, $0.1 \%$ SDS and $1 \mathrm{mM}$ EDTA, $\mathrm{pH}$ 7.4. The blots were then hybridized to a random primed, 0.9-kb cDNA fragment cloned from RAW 260.1 macrophage iNOS (25) (generously provided by Dr. C. F. Nathan, Cornell University Medical College, New York) [ ${ }^{32} \mathrm{P}$ ] dCTP-labeled to $1 \times 10^{8} \mathrm{cpm} / \mu \mathrm{g}$ of cDNA (random primer labeling kit; Amersham, Arlington Heights, IL). Hybridization was performed at $42^{\circ} \mathrm{C}$ for $15 \mathrm{~h}$ followed by washing under increasingly stringent conditions. To control for mRNA loading, blots were rehybridized with a ${ }^{32} \mathrm{P}$-dCTP-labeled human GAPDH cDNA.

Western analysis. Ventricular tissue was homogenized and isolated purified myocytes and infiltrating mononuclear cells were lysed in buffer containing $150 \mathrm{mM} \mathrm{NaCl}, 1.0 \% \mathrm{NP}-40,0.1 \%$ SDS, $1 \mathrm{mM}$ EDTA, and $50 \mathrm{mM}$ Tris, $\mathrm{pH} 7.7$ supplemented with protease inhibitors $(10 \mu \mathrm{g} / \mathrm{ml}$ of antipain and leupeptin, $1 \mathrm{mM}$ phenylmethylsulfonyl fluoride), and then centrifuged at $10,000 \mathrm{~g}$ for $20 \mathrm{~min}$ at $4^{\circ} \mathrm{C}$. Cytosolic protein $(25$ $\mu \mathrm{g}$ per lane) was separated on $8 \%$ SDS-polyacrylamide gel electrophoresis and transferred to nitrocellulose membranes. After overnight blocking in Tris-buffered saline with 3\% nonfat dried milk and 2\% BSA and subsequent washing, the blots were immunoblotted with the rabbit anti-macrophage iNOS antiserum $(1: 1,000)$ as described. An anti-rabbit Ig conjugated to horseradish peroxidase (Amersham), was used as secondary antibody. Blots were detected with the enhanced chemiluminescence method (Amersham).

Determinations of NO synthase activity. The excised hearts were rinsed and perfused with ice-cold saline to remove blood completely. Ventricular tissue was homogenized in ice-cold buffer containing 50 $\mathrm{mM}$ Tris- $\mathrm{HCl}, \mathrm{pH} 7.4,0.05 \mathrm{mM}$ EDTA, $0.5 \mathrm{mM}$ DL-dithiotreitol, 10 $\mu \mathrm{g} / \mathrm{ml}$ of antipain, leupeptin, and trypsin inhibitor and $0.1 \mathrm{mg} / \mathrm{ml}$ of phenylmethylsulfonyl fluoride. Homogenates were centrifuged at $100,000 \mathrm{~g}$ for $60 \mathrm{~min}$ at $4^{\circ} \mathrm{C}$. Supernatants were adjusted to a protein content of $2 \mathrm{mg} / \mathrm{ml}$ using BCA protein assay (Pierce, Rockford, IL) and bovine serum albumin as standard, and were used for the enzyme activity assay immediately. NO synthase activity was determined by incubation of the myocardial cytosolic enzyme preparations with 15 mM Hepes, pH 7.4, $2 \mathrm{mM}$ L-arginine or $0.35 \mu \mathrm{M}\left[{ }^{3} \mathrm{H}\right] \mathrm{L}$-arginine, 0.1 $\mathrm{mM} \mathrm{NADPH}$ and $2 \mathrm{mM} \mathrm{Mg}(\mathrm{OAc})_{2}$ for $20 \mathrm{~h}$ and then measurements of the formation of $\mathrm{NO}_{2}$ with the Greiss reagent and measurements of the conversion of $\left[{ }^{3} \mathrm{H}\right] \mathrm{L}$-arginine to $\left[{ }^{3} \mathrm{H}\right]$ citrulline by liquid scintillation counting of AG 50W-X8 column effluents (26).

Determination of cyclic GMP. Freshly isolated myocytes were extracted in ice-cold $0.1 \mathrm{~N} \mathrm{HCl}$ for $30 \mathrm{~min}$ and then centrifuged at 10,000 $g$ for $20 \mathrm{~min}$ at $4^{\circ} \mathrm{C}$. Supernatants were neutralized with $1.0 \mathrm{~N} \mathrm{NaOH}$ and protein content was measured as described above. Supernatants were kept at $-70^{\circ} \mathrm{C}$ and measured in a single assay using a cGMP radioimmunoassay kit (Amersham). The intra-assay coefficient of variation was $8 \%(n=5)$. 

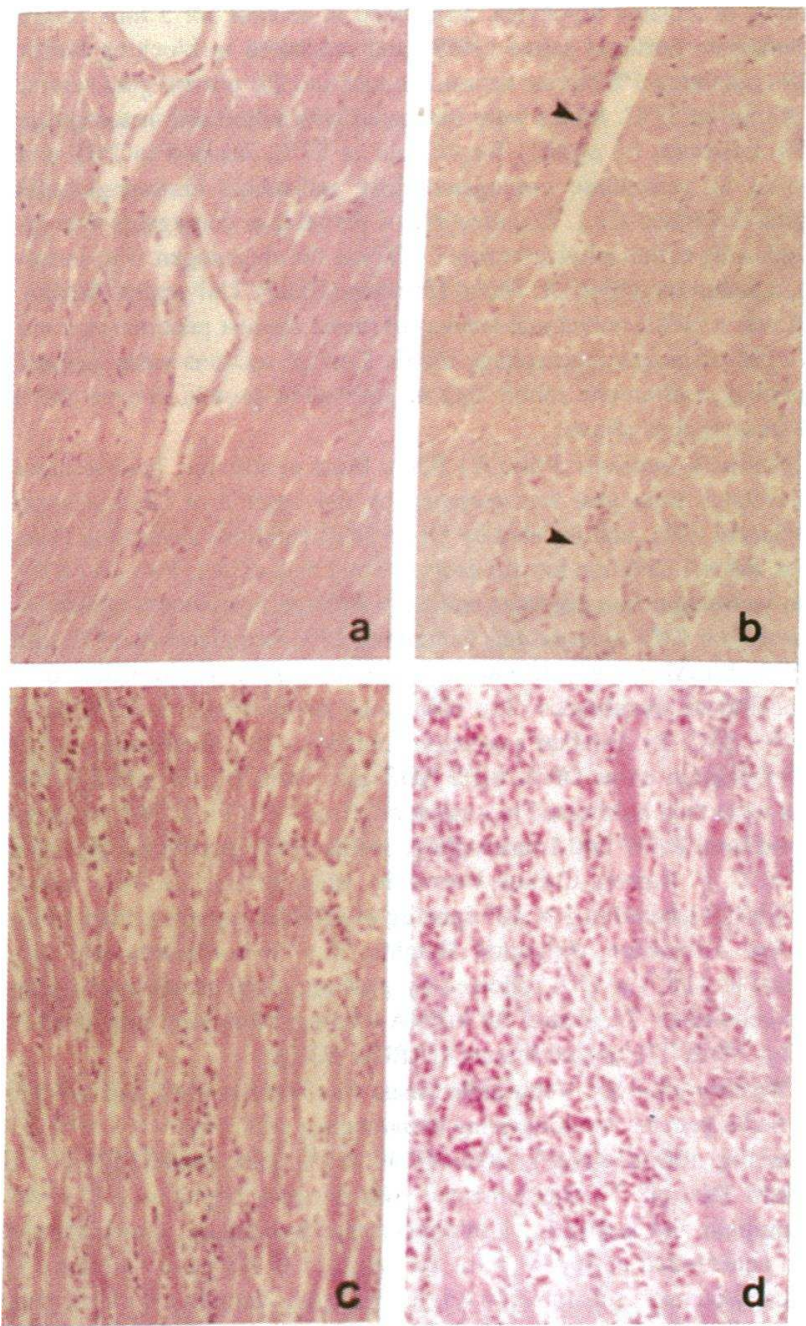

Figure 1. Time course of histology in cardiac allograft rejection. Sections of ventricular myocardium from cardiac allografts at day 1 after transplantation $(a)$ were histologically normal as were sections from syngeneic grafts. By day $3(b)$ there was a minor inflammatory infiltrate evident in the adventia of venules (arrowhead); cardiac myocytes appeared normal and there was no evidence of interstitial edema. At $5 \mathrm{~d}$ after transplantation $(c)$ hearts were edematous, revealed marked inflammatory infiltrate consisting of lymphocytes and macrophages, and there was necrosis of cardiac myocytes. After $6 \mathrm{~d}(d)$ there was extensive myocyte necrosis with accompanying inflammatory cells and edema. Hematoxylin and eosin. $\times 125$.

\section{Results}

The time course of the pathological changes in the WistarFurth:Lewis allogeneic allografts is depicted in Fig. 1. At day 1 the histology of the allogeneic allografts was normal as were the syngeneic grafts (Fig. $1 a$ ). At day 3 there was a slight infiltrate of lymphocytes and macrophages (Fig. $1 b$ ). At day 5 there was a marked inflammatory infiltrate of lymphocytes and macrophages with tissue edema and necrosis of myocytes (Fig. $1 c$ ). At day 6 necrosis of cardiac myocytes was more extensive (Fig. $1 d$ ). With this transplantation model cessation of the heart beat due to rejection usually occurs at 7 to $9 \mathrm{~d}$.

Northern analysis revealed abundant iNOS mRNA signal at
Figure 2. Northern blots from homogenates of rat ventricles at day 5 after transplantation. iNOS mRNA (12 mg poly (A) ${ }^{+}$ RNA/lane) was expressed in the tissue from the rejecting allogeneic cardiac allografts $(A)$ but not in the syngeneic control grafts $(S)$.
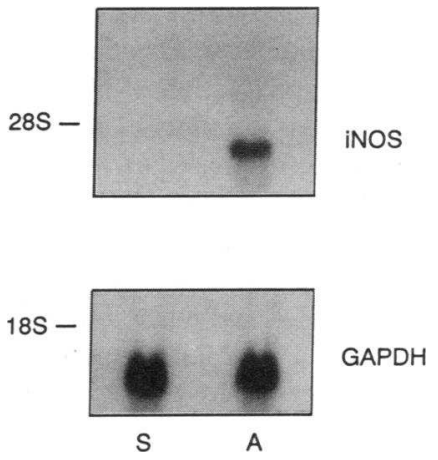

$4.3 \mathrm{~kb}$ in both ventricular homogenates (Fig. $2, n=3$ ) and isolated cardiac myocytes (Fig. 3, $n=3$ ) from rejecting cardiac allografts at day 5. However, there was no iNOS mRNA detected in the ventricular homogenates or isolated cardiac myocytes from syngeneic controls. The expression of GAPDH mRNA, a control for RNA loading, did not differ significantly in the two blots.

Using the rabbit polyclonal antiserum to peptide sequence 117-128 of macrophage iNOS, Western blotting identified a main protein iNOS band with an estimated molecular weight of $130 \mathrm{kD}$ in ventricular homogenates from the rejecting cardiac allografts but not from the syngeneic controls (Fig. 4, lanes 1 and $2 ; n=5$ ). Isolated cardiac myocytes from both sets of grafts were purified $>90 \%$ using a Percoll density gradient followed by adhesion of the myocytes to laminin coated dishes. Purification was assessed by staining cells of the myocyte fraction from the allografts with hematoxylin and eosin (Fig. $5 b$ ). Abundant iNOS was detected in isolated and purified myocytes from rejecting allografts (Fig. 4 , lane $4, n=5$ ), but not in purified myocytes from syngeneic controls (Fig. 4, lane 3). Cells from the rejecting allografts that sedimented on the Percoll gradient between 1.061 and $1.050 \mathrm{~g} / \mathrm{ml}$ were found to be a mixture of predominantly macrophages and some lymphocytes together with damaged cardiac myocytes (Fig. $5 a$ ). The iNOS protein was revealed in the mononuclear cell fraction from the rejecting allografts (Fig. 4, lane 6 ), while no band was visible in the same density gradient fraction from the syngeneic controls (Fig. 4, lane 5). The iNOS protein was not detected in Western blots of neonatal rat cardiac myocytes that had been maintained in tissue culture until there were no contaminating inflammatory cells (Fig. 4, lane 7); however, the iNOS protein was detected in cultured neonatal cardiac myocytes that had been treated for $24 \mathrm{~h}$ with cytokines (IL-1 $\beta 5 \mathrm{ng} / \mathrm{ml}$, IFN- $\gamma 9 \mathrm{ng} / \mathrm{ml}$, and TNF $\alpha$

Figure 3. Northern blots from isolated cardiac myocytes. iNOS message $\left(1.6 \mathrm{mg}\right.$ poly $(\mathrm{A})^{+}$ RNA/lane) was expressed in myocytes from the rejecting allogeneic cardiac allografts $(A)$ but not from syngeneic control grafts $(S)$.
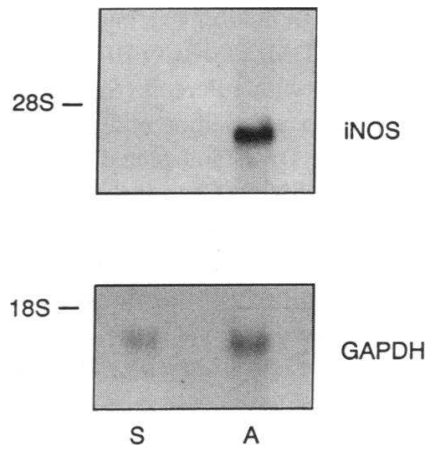


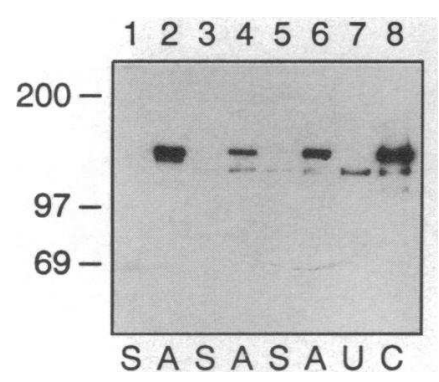

Figure 4. Western analysis of iNOS enzyme in rat hearts at day 5 after transplantation. Cytosolic protein $(25 \mu \mathrm{g} / \mathrm{lane})$ from ventricular tissue homogenates (lanes 1 and 2), and isolated and purified myocytes (lanes 3 and 4 ), as well as mononuclear cells (lanes 5 and 6 ) was separated by $8 \%$ SDS-PAGE and transferred to nitrocellulose mem-

brane. Immunoblot was performed with polyclonal antiserum raised against a peptide of macrophage inducible NO synthase and identified one main band with an estimated molecular weight of $130 \mathrm{KD}$ in allogeneic cardiac samples, but not in syngeneic control samples. $A$, allogeneic; $S$, syngeneic. NO synthase in neonatal myocytes (lanes 7 and 8 ) was induced by $5 \mathrm{ng} / \mathrm{ml}$ of IL- $1 \beta, 9 \mathrm{ng} / \mathrm{ml}$ of IFN- $\gamma$, and $25 \mathrm{ng} / \mathrm{ml}$ of TNF- $\alpha$ as positive control. $U$, untreated; $C$, cytokine treated.

$25 \mathrm{ng} / \mathrm{ml}$ ) known to induce the enzyme in these cells (Fig. 4, lane 8 ). Western blots from syngeneic and allogenic grafts on days 1 and 3 revealed no detectable iNOS band.

Myocardial cytosolic iNOS preparations were made from $100,000 \mathrm{~g}$ supernatants of ventricular homogenates. The activity of iNOS was assessed by incubating the crude enzyme preparations with L-arginine and cofactors specific for the inducible enzyme and measurement of nitrite with the Greiss reagent. Nitrite formation from L-arginine was increased significantly in the rejecting allografts in comparison to the low basal levels observed in the syngeneic controls at day 5 (Fig. $6, n=6, P$ $<.01)$. Only minimal levels of nitrite were detected at days 1 and 3 from allogeneic grafts $(n=2)$. Conversion of $\left[{ }^{3} \mathrm{H}\right] \mathrm{L}-$ arginine to $\left[{ }^{3} \mathrm{H}\right] \mathrm{L}$-citrulline by the cytosolic enzyme from the rejecting allografts at day 5 was also increased significantly to levels that were $280 \pm 47 \%$ of syngeneic controls. Cyclic GMP levels were also measured in ventricular myocytes isolated from both sets of grafts at day 5 after transplantation (Fig. 7). Cyclic GMP levels were increased significantly in cardiac myocytes
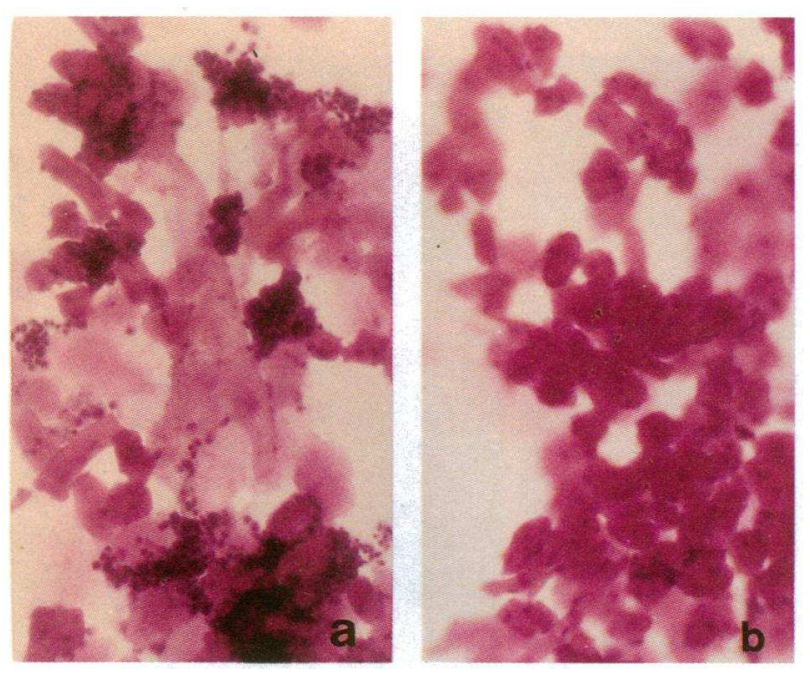

Figure 5. Cytospin preparations of the purified cardiac myocyte fraction from representative samples used for the Western blots are shown above (b) as well as the cell fraction from the density gradient between 1.061 $1.050 \mathrm{~g} / \mathrm{ml}$ containing mononuclear cells and damaged cardiac myocytes $(a)$. Hematoylin and eosin. $\times 125$.

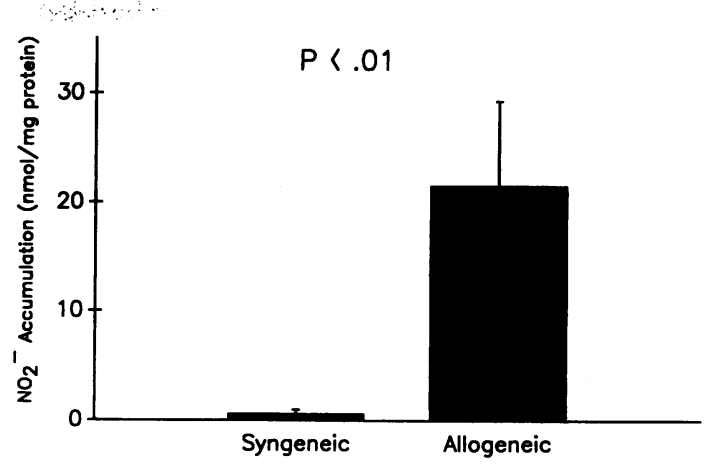

Figure 6. Comparison of iNOS activity in allogeneic and syngeneic ventricular tissue at day 5 after transplantation. The crude enzyme preparations as described in Methods were incubated with $L$-arginine and cofactors at $37^{\circ} \mathrm{C}$ for $20 \mathrm{~h} ; \mathrm{NO}_{2}{ }^{-}$production in the reaction mixture was determined in duplicate by the Griess reaction. Each bar represents the mean \pm SEM of the six rat hearts within each group.

isolated from rejecting allografts above the levels found in myocytes from syngeneic grafts $(n=3, P<.05)$.

Immunostaining using the same rabbit anti-iNOS antiserum and a double antibody peroxidase technique was performed on frozen sections obtained from the rejecting cardiac allografts and from the syngeneic grafts. Increased peroxidase staining indicative of iNOS was observed in macrophages and lymphocytes and in some microvascular endothelial cells interspersed between cardiac muscle fibers of the rejecting cardiac allografts (Fig. 8, left panel). There was also increased staining indicative of iNOS in a diffuse cytoplasmic pattern associated with the periphery of the cardiac muscle fibers of the rejecting allografts (Fig. $8 a$ ). These changes were not observed in sections from the syngeneic grafts (Fig. $8 \mathrm{c}$ ). Isolated and purified myocytes from both sets of grafts were also immunostained with the anti-iNOS antiserum. The purified myocytes from the rejecting cardiac allografts revealed a diffuse peripheral pattern of increased iNOS staining (Fig. $9 b$ ) in comparison with purified myocytes from the syngeneic grafts (Fig. $9 c$ ). The mononuclear cell fraction from the rejecting allografts also showed increased iNOS staining (Fig. $9 a$ ). In addition, the neonatal cultured myocytes in which NOS had been induced by treatment with cytokines showed positive iNOS staining whereas unstimu-

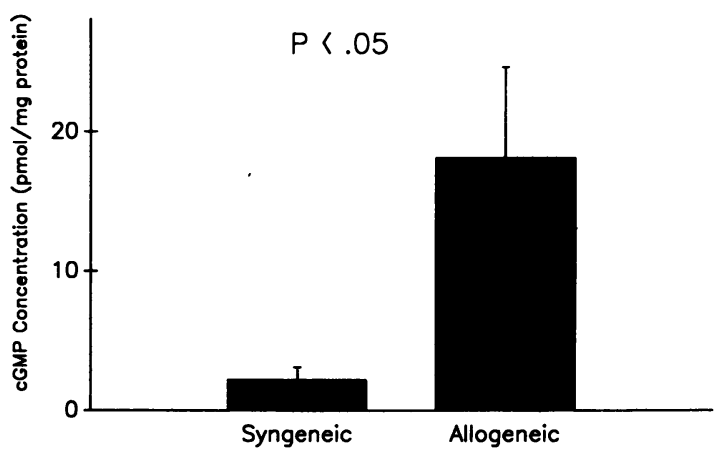

Figure 7. Comparison of cyclic GMP levels in allogeneic and syngeneic cardiac myocytes at day 5 after transplantation. Cyclic GMP in isolated cardiac myocytes was extracted and determined in duplicate, as described. Each bar is the mean \pm SEM of the three rat hearts within each group. 

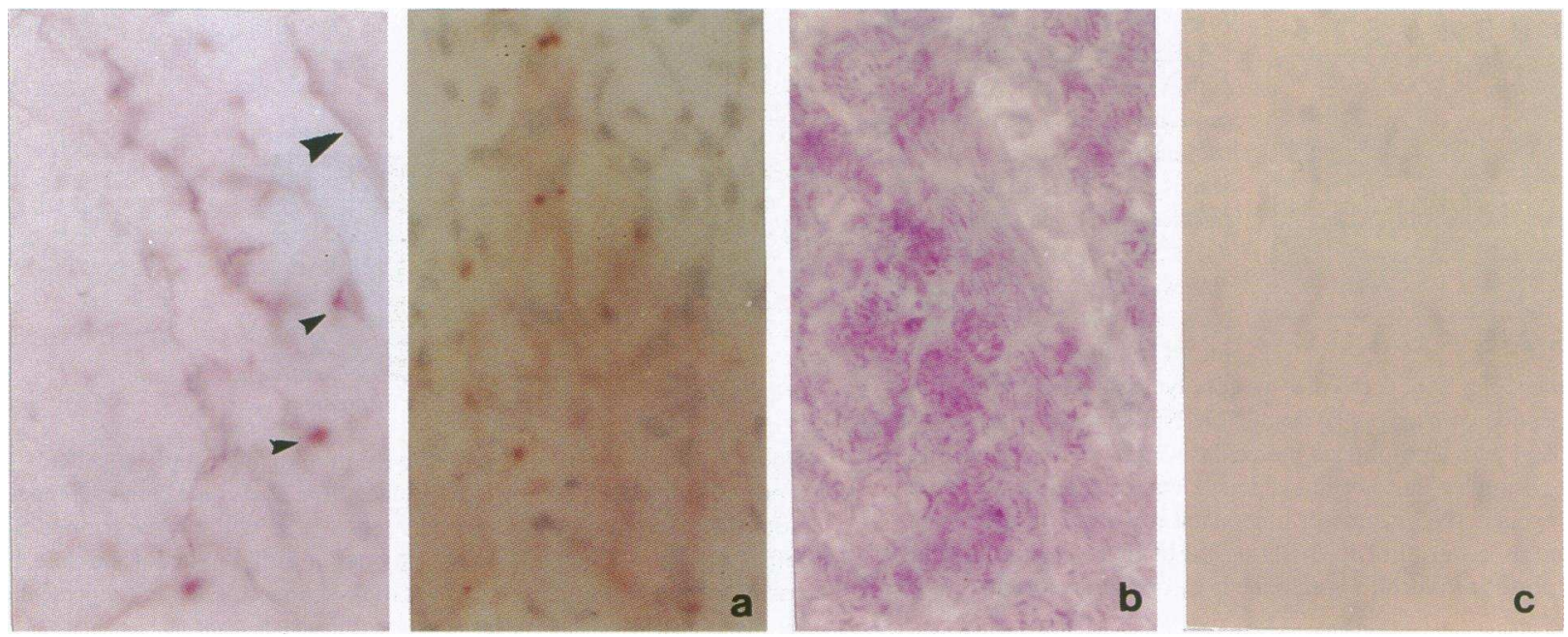

Figure 8. Immunostaining for iNOS. Frozen sections of ventricular myocardium from a rejecting allograft $5 \mathrm{~d}$ after transplant stained with rabbit anti-iNOS $(a)$. The left panel displays immunoreactivity in the vascular endothelium (large arrowhead) and infiltrating inflammatory cells (small arrowhead); on the right panel the reaction product is evident in the periphery of cardiac myocytes and in inflammatory cells. An adjacent section stained with hematoxylin and eosin is shown $(b)$. A comparable section from a syngeneic control graft showed no immunoreactivity $(c)$. $\times 300$.

lated neonatal myocytes were negative (Fig. 10, $a$ and $b$ ). Neither tissue sections nor purified myocytes or inflammatory cells showed positive immunostaining with control nonimmune serum (data not shown).

\section{Discussion}

The data from this study demonstrate for the first time that the inducible NO synthase mRNA, protein, and enzyme activity are expressed in the myocardium during cardiac allograft rejection. Significant levels of iNOS were not present in syngeneic control hearts. The iNOS mRNA and protein were also present in isolated purified myocyte preparations from the rejecting allografts. Immunocytochemistry indicated that iNOS protein was increased in macrophages infiltrating the myocardium and in cardiac muscle fibers and in isolated purified cardiac myocytes from the rejecting allografts. The increased iNOS activity in the rejecting cardiac allografts was associated with significant increases in myocardial cyclic GMP content and with depressed ventricular contractility as indicated by palpation of weakened cardiac contractions in vivo. The increased iNOS activity in the rejecting cardiac allografts was also associated with histological evidence of myocardial edema and patchy necrosis of cardiac muscle fibers.

The iNOS mRNA in the myocardial tissue and isolated cardiac myocytes from the rejecting hearts was measured using a cDNA cloned from RAW 260.1 macrophages by Xie et al. (25) and the enzyme protein was assessed in Western blots
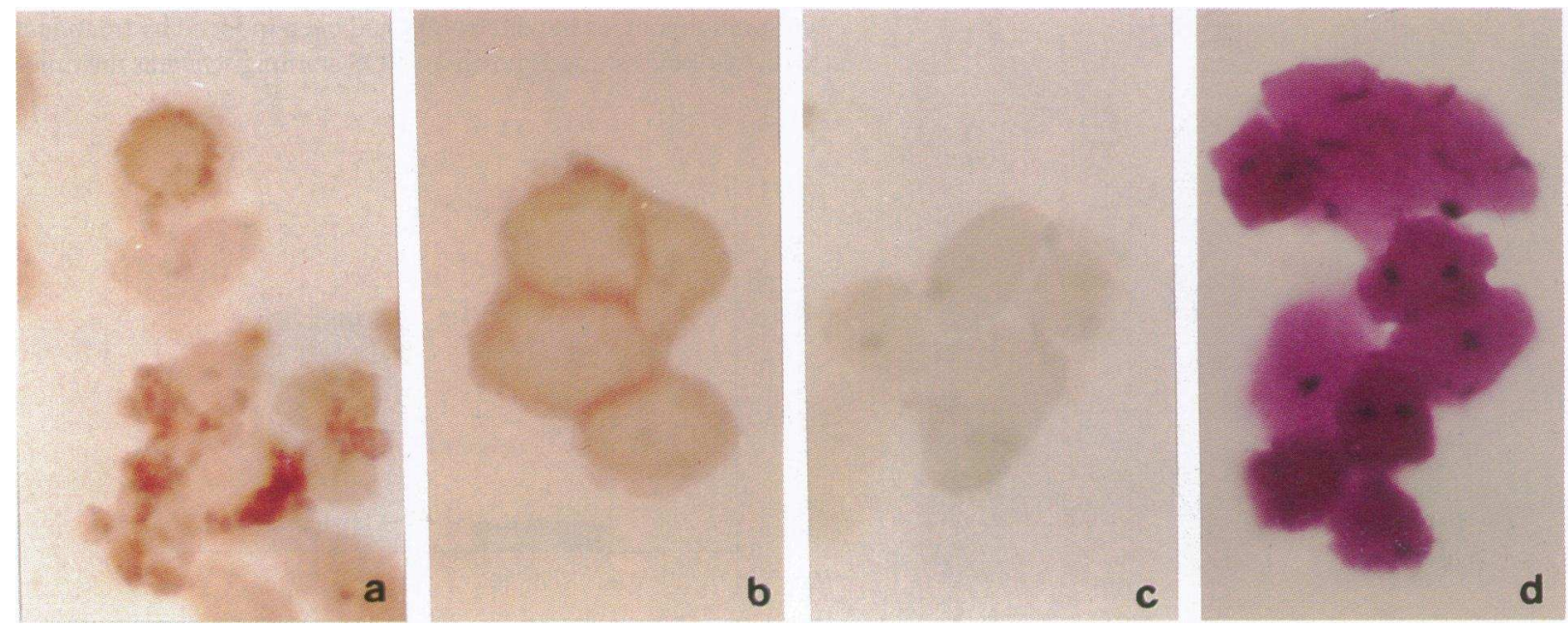

Figure 9. The isolated and purified myocytes from a rejecting allograft $(b)$ revealed a diffuse punctate pattern of increased iNOS immunostaining which appears more intense along the plasma membrane in comparison to myocytes from a syngeneic control graft $(c)$. Mononuclear cell-rich fraction from rejecting allograft $(a)$ also showed increased iNOS staining of both macrophages and myocytes. Hematoxylin and eosin stained myocytes $(d)$ from the same sample as shown in $(b) . \times 300$. 
a

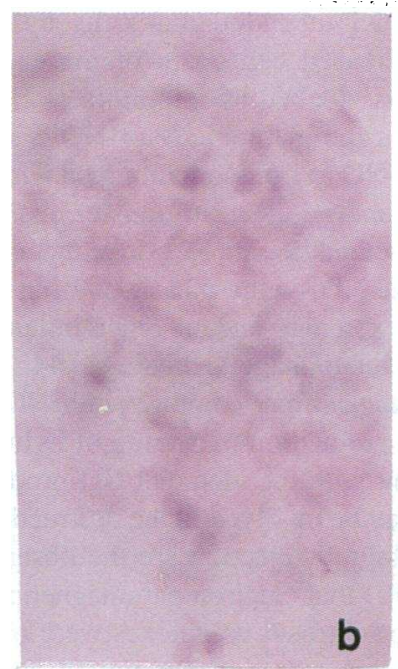

Figure 10. Primary cultures of neonatal myocytes treated with $5 \mathrm{ng} / \mathrm{ml}$ of IL- $1 \beta, 9 \mathrm{ng} / \mathrm{ml}$ of IFN- $\gamma$ and $25 \mathrm{ng} / \mathrm{ml}$ of TNF- $\alpha$ for $24 \mathrm{~h}(a)$ revealed increased iNOS immunoreactivity in comparison to untreated control myocytes $(b) . \times 300$.

using a polyclonal antibody raised against a peptide corresponding to amino acids 117 to 128 of macrophage iNOS. The nucleotide sequence for the isoform of iNOS in cardiac myocytes has not yet been published, but preliminary data indicates that it is nearly identical to that of the macrophage enzyme (15). Using the cDNA for macrophage iNOS, Northern analysis demonstrated iNOS mRNA in ventricular tissue and cardiac myocytes from the rejecting cardiac allografts and also in J774.1 macrophages (26) and in neonatal rat cardiac myocytes and adult cardiac myocytes (data not shown) that had been stimulated with cytokines.

Western blots indicated the presence of iNOS protein in cardiac myocytes isolated and purified from the rejecting allografts and also in a fraction from the density gradient that was enriched in mononuclear cells and damaged cardiac myocytes. Using the same polyclonal antiserum Western blots revealed the characteristic iNOS protein band in J774.1 macrophages (26), neonatal cardiac myocytes and in adult rat cardiac myocytes (unpublished data) that had been stimulated with cytokines.

At day five after heart transplantation the cellular infiltrate in the rejecting myocytes was primarily macrophages and lymphocytes along with a few polymorphonuclear leukocytes. Increased immunostaining for iNOS was apparent in the infiltrating macrophages and also in some of the lymphocytes in the tissue sections. Mononuclear staining for iNOS was also very apparent in the fraction from the density gradient that contained macrophages attached to damaged cardiac myocytes. Endothelial cells lining small vessels in the rejecting allografts also revealed increased immune staining for iNOS.

In different cell systems NO functions as both a paracrine as well as an autocrine messenger to transduce intracellular biochemical events. NO produced by iNOS in the infiltrating macrophages may affect adjacent cardiac myocytes in a fashion analogous to the effects of NO synthesized by endothelial and endocardial cells to depress the contractile function of adjacent heart muscle cells $(11,13,27)$. Hoffman, Langrehr and colleagues have also reported evidence that NO synthesis by lym- phocyte subsets may modulate alloantigen-induced activation of cytotoxic lymphocytes in vivo during the allograft response $(28-30)$.

Immunostaining of cardiac myocytes with the rabbit antiserum to iNOS was more intense in cardiac muscle fibers and in purified cardiac myocytes from the rejecting hearts than in tissue sections and isolated and purified cardiac myocytes from the syngeneic grafts. These findings, plus the significant amount of iNOS protein apparent on the Western blots from ventricular tissue and from the isolated and purified cardiac myocytes from the rejecting allografts, provide additional evidence that iNOS was induced not only in inflammatory cells but also in the cardiac myocytes during transplant rejection. Whether NO produced by iNOS in cardiac muscle cells during transplant rejection influences cardiac performance is unknown at this time. Autocrine effects of NO produced in heart muscle to reduce myocardial contractility have been reported, however (12, $16,31)$.

The enzyme activity of iNOS in the rejecting hearts was several fold higher than the low level of activity found in syngeneic control grafts. The enzyme activity of iNOS is directly influenced by the availability of the substrate L-arginine, is continuous for long periods of time and produces much higher levels of nitric oxide than those produced by the constitutive isoforms (5-7). The activity of the constitutive NO synthases is dependent upon calcium and calmodulin, whereas that of iNOS does not require calcium and calmodulin which were omitted from the incubation mixture used to assess enzyme activity $(5,7,25,32)$. The finding that iNOS enzyme activity is increased in rejecting cardiac allografts is consistent with related data obtained in transplant models by others. Langrehr and colleagues $(29,30)$ reported that the blood levels of nitrite, the stable breakdown product of NO, were increased in rats during renal, liver and cardiac allograft rejection (30) and that nitrite levels also rose significantly in a sponge allograft model of rejection (29). In endomyocardial biopsy specimens from patients with dilated cardiomyopathy iNOS enzyme activity was also reported to be higher than in biopsies that were histologically normal from other patients (33).

Nitric oxide acts upon its target molecule soluble guanylyl cyclase to stimulate the formation of cyclic GMP (5-7). Cyclic GMP levels in isolated cardiac myocytes from rejecting cardiac allografts with increased iNOS mRNA, protein and enzyme activity were elevated markedly above levels found in myocytes from the syngeneic grafts. This result is similar to that of Schultz et al who observed increased cyclic GMP in myocardium from guinea pig hearts in which iNOS had been induced with IFN$\gamma$ and endotoxin (13). In studies by Brady et al. (31) the amplitude of contraction of isolated cardiac myocytes was reduced in cells from animals treated with endotoxin to induce iNOS (31) and also was reduced in a dose dependent fashion in myocytes from normal guinea pigs that were incubated in media containing NO or the NO donor sodium nitroprusside (9). The latter effect was duplicated by incubating the cardiac myocytes in media containing increasing concentrations of the cyclic GMP analogue, 8-bromo-cyclic GMP (9).

It is probable that cytokines released by $\mathrm{T}$ lymphocytes and macrophages involved in the immunological response to foreign antigens are responsible for the induction of iNOS during cardiac allograft rejection $(3,4)$. Among the cytokines that have been detected in rejecting organs are the interleukins 1,2 , and 4 , IFN- $\gamma$ and TNF $\alpha(4,17)$. Although the specific panel of 
cytokines responsible for iNOS induction in rejecting hearts is currently unknown, evidence exists that cytokines elaborated by the Th-1 subset of T lymphocytes may contribute to iNOS induction in other experimental systems $(18,19)$. In macrophages iNOS expression has been induced by exposure of the cells to IFN- $\gamma$, bacterial endotoxin, TNF $\alpha$ or IL- $\beta(5,25,34$, $35)$. The expression of iNOS has also been induced in endothelial cells (36), in vascular smooth muscle cells (37), and in arterial ring preparations (6) by incubation with the same cytokines. Schulz et al. (13) reported that iNOS activity was induced in guinea pig hearts and in isolated adult cardiac myocytes from guinea pig hearts in response to treatment with IFN- $\gamma$ and bacterial endotoxin. Roberts et al. (14) demonstrated that IL$1 \beta$ caused an induction of iNOS activity and mRNA in neonatal rat cardiac myocytes maintained in tissue culture, and that this induction of iNOS was inhibited by treatment of the cells with transforming growth factor beta. In preliminary studies, Balligand et al. (15) and we (unpublished data) have induced iNOS mRNA in adult rat cardiac myocytes incubated with $\mathrm{IL}-1 \beta$, IFN- $\gamma$, and TNF $\alpha$.

Although the present studies provide evidence that cardiac allograft rejection induces iNOS in cardiac muscle cells and macrophages infiltrating the allograft, they do not document the functional consequences of iNOS induction in this setting. Hypotension, reduced cardiac output, and diminished pressor responses to catecholamine infusions are the hemodynamic characteristics of late stage human cardiac transplantation rejection. Necrosis of cardiac muscle fibers and tissue edema are histological consequences of the rejection process. Ongoing investigations in our laboratory will attempt to define the role of iNOS induction in both of these consequences by demonstrating the effect of inhibitors of iNOS enzyme activity and of iNOS induction upon the hemodynamic and pathological sequelae of allograft rejection in this model.

Conceivably, high levels of NO produced by iNOS induced in cardiac myocytes and in infiltrating macrophages during allograft rejection could modify ventricular contractility and the responses of heart muscle to muscarinic and adrenergic stimuli. Administration of inhibitors of NOS to isolated perfused normal hearts $(5,12,16)$ or to isolated myocytes from normal adult rat hearts was not associated with significant changes in contractile force or amplitude. However, Finkel et al. (38) observed that administration of cytokines acutely depressed tension development in rat papillary muscles, an effect which was reversed by administration of drugs which inhibit NOS. In studies by Balligand and co-workers, inhibitors of NO synthesis or activity impeded muscarinic retardation of the beating rate of neonatal myocytes and augmented the inotropic responses of both neonatal and adult rat cardiac myocytes to beta adrenergic agonists $(12,16)$. The induction of iNOS by endotoxin in guinea pig hearts by Brady et al. (31) was associated with reduced amplitude of basal contraction which was partially reversed by inhibition of NOS.

The causes of the necrosis of cardiac myocytes that is characteristic of cardiac allograft rejection are incompletely understood and have been attributed primarily to actions of cytotoxic lymphocytes $(4,17)$. NO synthesized by iNOS in macrophages and cardiac myocytes may also exert cytotoxic effects on the heart muscle cells during allograft rejection. Evidence has been accumulated that NO synthesized by iNOS in activated macrophages is cytostatic and cytotoxic to bacteria and parasites and to tumor and pancreatic islet cells $(36,39-42)$. Induction of
iNOS in endothelial cells by cytokines was associated with increased cell death of the endothelial cells, an effect which was blocked by inhibitors of NO synthesis (43). It is believed that the cytotoxicity of NO is mediated in part by the binding of NO to iron-containing enzymes such as enzymes in the mitochondrial electron transfer chain (complexes I, IV, V), aconitase and ribonucleotide reductase $(5,7,35,39-42)$. The inducible NO synthase has also been implicated in autoimmune complex injury and in other inflammatory reactions that produce tissue damage and edema $(44,45)$. In these situations, oxygen radicals may combine with NO to form perioxynitrite leading to production damaging of hydroxyl radicals $(46,47)$. Consistent with the idea that NO produced by inducible NO synthase may be involved in the destruction of heart tissue during cardiac allograft rejection are the observations by Lancaster and et al. (48) that electron paramagnetic resonance signals indicative of iron-nitrosyl complexes were observed in rat cardiac allografts during rejection but not in control syngeneic grafts or other tissues of the transplanted animals (48).

\section{Acknowledgments}

This work was supported in part by grant HL21006 from the National Institutes of Health.

\section{References}

1. The Registry of the International Society for Heart and Lung Transplantation: Tenth Official Report. 1993. J. Heart Lung Transplant. 12(4):543-548.

2. Billingham, M. E. 1987. Cardiac transplant atherosclerosis. Transplant. Proc. 19:19-25.

3. Tilney, N. L., J. W. Kupiec-Woglinski, C. D. Heidecke, P. A. Lear, and T. B. Strom. Mechanisms of rejection and prolongation of vascularized organ allografts. Immunol. Rev. 78:185-216.

4. Wu, C. J., M. Lovett, J. Wong-Lee, F. Moeller, M. Kitamura, T. J. Goralski, M. E. Billingham, V. A. Starnes, and C. Clayberger. 1992. Cytokine gene expression in rejecting cardiac allografts. Transplantation. 54:326-332.

5. Moncada, S. 1992. The L-arginine: nitric oxide pathway. Acta. Physiol. Scand. 145:201-227.

6. Ignarro, L. J. 1990. Biosynthesis and metabolism of endothelium-derived nitric oxide. Ann. Rev. Toxicol. 30:535-560.

7. Lowenstein, C. J., and S. H. Snyder. 1992. Nitric oxide, a novel biologic messenger. Cell. 70:705-707.

8. Amezcua, J. L., R. M. J. Palmer, B. M. de Souza, and S. Moncada. 1989. Nitric oxide synthesized from L-arginine regulates vascular tone in the coronary circulation of the rabbit. Br. J. Pharmacol. 97:1119-1124.

9. Kelm, M., and J. Schrader. 1990. Control of coronary vascular tone. Circ. Res. 66:1561-1575.

10. Schulz, R., J. A. Smith, M. J. Lewis, and S. Moncada. 1991. Nitric oxide synthase in cultured endocardial cells of the pig. Br. J. Pharmacol. 104:21-24.

11. Brady, A. J. B., J. B. Warren, P. A. Poole-Wilson, T. J. Williams, and S. E. Harding. 1993. Nitric oxide attenuates cardiac myocyte contraction. Am. J. Physiol. 265:H176-H182.

12. Balligand, J. -L., R. A. Kelly, P. A. Marsden, T. W. Smith, and T. Michel. 1993. Control of cardiac muscle cell function by an endogenous nitric oxide signaling system. Proc. Natl. Acad. Sci. USA. 90:347-351.

13. Schulz, R., E. Nava, and S. Moncada. 1992. Induction and potential biological relevance of a $\mathrm{Ca}^{2+}$-independent nitric oxide synthase in the myocardium. Br. J. Pharmacol. 105:575-580.

14. Roberts, A. B., Y. Vodouotz, N. S. Roche, M. B. Sporn, and C. F. Nathan. 1992. Role of nitric oxide in antagonistic effects of transforming growth factor$\beta$ and interleukin- $1 \beta$ on the beating rate of cultured cardiac myocytes. Mol. Endocrinol. 6:1921-1930.

15. Balligand, J. L., D. Ungureanu, D. Pimental, R. A. Kelly, T. W. Smith, and T. Michel. 1993. Detection of transcripts for a cytokine inducible nitric oxide synthase isoform in adult rat ventricular myocytes. Circulation. 88:1-384.

16. Balligand, J.-L., D. Ungureanu, R. A. Kelly, L. Kobzik, D. Pimental, T. Michel, and T. W. Smith. 1993. Abnormal contractile function due to induction of nitric oxide synthesis in rat cardiac myocytes follows exposure to activated macrophage-conditioned medium. J. Clin. Invest. 91:2314-2319.

17. Krensky, A. M. 1994. T cells in autoimmunity and allograft rejection. Kidney Int. 45:S-50-S-56. 
18. Liew, F. Y., Y. Li, A. Severn, S. Millott, J. Schmidt, M. Salter, and S. Moncada. 1991. A possible novel pathway of regulation by murine helper type$2\left(\mathrm{Th}_{2}\right)$ cells of a $\mathrm{Th}_{1}$ cell activity via modulation of the induction of nitric oxide synthase on macrophages. Eur. J. Immunol. 21:2489-2494.

19. Taylor-Robinson, A. W., R. S. Phillips, A. Severn, S. Moncada, and F. Y. Liew. 1993. The role of $\mathrm{Th}_{1}$ and $\mathrm{Th}_{2}$ cells in a rodent malaria infection. Science (Wash. DC). 260:1931-1933.

20. Ono, K., and E. S. Lindsay. 1969. Improved technique of heart transplantation in rats. J. Thorac. Cardiovasc. Surg. 7:225-229.

21. Wittenberg, B. A., and T. Robinson. 1981. Oxygen requirement, morphology, cell coat membrane permeability of calcium-tolerant myocytes from hearts of adult rats. Cell Tissue Res. 216:231-251.

22. Osbakken, M., T. Ivanics, D. Zhang, R. Mitza, and H. Blum. 1992. Isolated cardiomyocytes in conjunction with NMR spectroscopy techniques to study metabolism and ion flux. J. Biol. Chem. 15340-15347.

23. Eid, H., D. M. Larson, J. P. Springhorn, M. A. Attawia, R. C. Nayak, T. W. Smith, and R. A. Kelly. 1992. Role of epicardial meseothelial cells in the modification of phenotype and function of adult rat ventricular myocytes in primary culture. Circ. Res. 71:40-50.

24. Chomozynski, P., and N. Sacchi. 1987. Single step method of RNA induction by acid guanidinium-thiocyanate-phenol-chloroform extraction. Anal. Biochem. 162:156-159.

25. Xie, Q-W., H. J. Cho, J. Calaycay, R. A. Mumford, K. M. Swiderek, T. D. Lee, A. Ding, T. Troso, and C. Nathan. 1992. Cloning and characterization of inducible nitric oxide synthase from mouse macrophages. Science (Wash. DC). 256:225-228.

26. Yang, X., B. Cai, R. R. Sciacca, and P. J. Cannon. 1994. Inhibition of inducible nitric oxide synthase in macrophages by oxidized low density lipoproteins. Circ. Res. 74:318-328.

27. Brutsaert, D. L. 1993. Endocardial and coronary endothelial control of cardiac performance. NIPS. 8:82-88.

28. Hoffman, R. A., J. M. Langrehr, T. R. Billiar, R. D. Curran, and R. L. Simmons. 1990. Alloantigen-induced activation of rat splenocytes is regulated by the oxidative metabolism of L-arginine. J. Immunol. 145:2220-2226.

29. Langrehr, J. M., R. A. Hoffman, T. R. Billiar, K. K. W. Lee, W. H. Schraut, and R. L. Simmons. 1991. Nitric oxide synthesis in the in vivo allograft response: A possible regulatory mechanism. Surgery. 110:335-342.

30. Langrehr, J. M., N. Murase, P. M. Markus, X. Cai, P. Neubaus, W. Schraut, R. L. Simmons, and R. A. Hoffman. 1992. Nitric oxide production in host-versus-graft and graft-versus-host reactions in the rat. J. Clin. Invest. 90:679683.

31. Brady, A. J. B., P. A. Poole-Wilson, S. E. Harding, and J. B. Warren. 1992. Nitric oxide production within cardiac myocytes reduces their contractility in endotoxemia. Am. J. Physiol. 263:H1963-H1966.

32. Cho, H. J., Q. Xie, J. Calaycay, R. H. Mumford, K. M. Swiderick, T. D. Lee, and C. Nathan. 1992. Calmodulin is a subunit of nitric oxide synthase from macrophages. J. Exp. Med. 176:599-604.

33. de Belder, A. J., M. W. Radomski, H. J. F. Why, P. J. Richardson, C. A.
Bucknall, E. Salas, J. F. Martin, and S. Moncada. 1993. Nitric oxide synthase activities in human myocardium. Lancet. 341:84-85.

34. Stuehr, D. J., and M. A. Marletto. 1985. Mammalian nitrate biosynthesis: mouse macrophages produce nitrite and nitrate in response to Escherichia coli lipopolysacchoride. Proc. Natl. Acad. Sci. USA. 82:7738-7742.

35. Drapier, J-C., J. Weizesbin, and J. B. Hibbs. 1988. Interferon $\gamma$ and tumor necrosis factor induce the L-arginine-dependent cytotoxic effector mechanism in murine macrophages. Eur. J. Immunol. 18:1587-1592.

36. Kilbourn, R. G., and I. Belloni. 1990. Endothelial cell production of nitrogen oxides in response to interferon in combination with tumor necrosis factor, interleukin-1 or endotoxin. J. Natl. Cancer Inst. 82:772-776.

37. Busse, R., and A. Mülsch. 1990. Induction of nitric oxide synthase by cytokines in vascular smooth muscle cells. FEBS (Fed. Eur. Biochem. Soc.) Lett. 175:87-90.

38. Finkel, M. S., C. V. Oddis, T. D. Jacob, S. C. Watkins, B. G. Hattler, and R. L. Simmons. 1992. Negative inotropic effects of cytokines on the heart mediated by nitric oxide. Science (Wash. DC). 257:387-389.

39. Stuehr, D. J., and C. F. Nathan. 1989. Nitric oxide: A macrophage product responsible for cytostasis and respiratory inhibition in tumor target cells. J. Exp. Med. 169:1543-1555.

40. Drapier, J.-C., C. Pellat, and Y. Henry. 1991. Generation of EPR-detectable nitrosyl-iron complexes in tumor target cells cocultured with activated macrophages. J. Biol. Chem. 266:10162-10167.

41. Lancaster, J. R., Jr., and J. B. Hibbs, Jr. 1990. EPR demonstration of ironnitrosyl complex formation by cytotoxic activated macrophages. Proc. Natl. Acad. Sci. USA. 87:1223-1227.

42. Kröncke, K-D., V. Kolb-Bachofen, B. Berschick, V. Burkan, and H. Kolb. 1991. Activated macrophages kill pancreatic syngeneic islet cells via argininedependent nitric oxide generation. Biochem. Biophys. Res. Comm. 175:752-758.

43. Palmer, R. M. J., L. Bridge, N. A. Foxwell, and S. Moncada. 1992. The role of nitric oxide in endothelial cell damage and its inhibition by glucocorticoids. Br. J. Pharmacol. 105:11-12.

44. Mulligan, M. S., J. M. Hevel, M. A. Marletta, and P. Ward. 1991. Tissue injury caused by deposition of immune complexes is L-arginine dependent. Proc. Natl. Acad. Sci. USA. 88:6338-6342.

45. Ialenti, A., A. Ianaro, S. Moncada, and M. Di Rosa. 1992. Modulation of acute inflammation by endogenous nitric oxide. Eur. J. Pharmacol. 211:177182.

46. Beckman, J. S., T. W. Bechman, J. Chen, P. A. Marshall, and B. A. Freeman. 1990. Apparent hydroxyl radical production by perioxynitrite: implications for endothelial injury from nitric oxide and superoxide. Proc. Natl. Acad. Sci. USA. 87:1020-1024.

47. Hogg, N., V. M. Darley-Usmar, M. T. Wilson, and S. Moncada. 1992. Production of hydroxyl radicals from the simulatneous generation of superoxide and nitric acid. Biochem. J. 281:419-424.

48. Lancaster, J. R. Jr., J. M. Langrehr, H. A. Bergonia, N. Murasc, R. L. Simmons, and R. A. Hoffman. 1992. EPR detection of heme and nonheme ironcontaining protein nitrosylation by nitric oxide during rejection of rat heart allograft. J. Biol. Chem. 267:10994-10998. 